\title{
The Significance of the Agrarian reform in Nicaragua
}

\author{
Wilm Johannes \\ Goldsmiths College, University of London, UK \\ j.wilm@gold.ac.uk
}

\begin{abstract}
The term "land reform" is in Nicaragua often-times presented as a feature only associated with the government of the Frente Sandinista de Liberación Nacional (FSLN) of the 1980s (see for example Rocha, 2010; "Land reform reformed," 1997; Zalkin, 1990), yet in this article I argue that some type of land redistribution has been the policy of all governments both before and after the 1980s, and that this process continues during the current FSLN government, but that the direction and the magnitude of the redistribution has changed significantly over time. One needs to understand this history and the considerations about Nicaraguans make about previous land redistribution patterns in order to make sense of what land ownership means in this country. While the land reform of the 1980s was the most direct redistribution, this article argues that land reform in favor of small-scale producers has been taken up again after 2007, even though it does not form part of official government policy. At the same time other factors seem to be if more importance in lowering economic differences.
\end{abstract}

Keywords: Latin America; political anthropology; history; Nicaragua; revolutionary movements

\section{Introduction}

The Nicaraguan Sandinista revolution of 1979 and the subsequent land reform of the 1980s as well as other key policies of the Sandinista-led government were followed by a global audience. The Nicaraguan revolutionaries were supported both by the Soviet Union as well as western European trade unions and social democrats, while the US was opposed to the new Nicaraguan government and it financed a war against it. In 1990 a right wing government took power, and the Sandinistas did not return to power until 2007. Land reform has not been an official policy since then and many of the radical views have been toned down. The Sandinistas have lost most of the support they previously had from European progressives. Largely this can be attributed to a view that policies like the land reform of the 1980s were uniquely positive in terms of their impact for small-scale producers. This article tries to show that the question of land reform and economic impact has been very complex throughout the past decades of Nicaraguan history, and that it continues to be a difficult terrain. It also attempts to show that the positive impact for low income groups of the policies of the 1980s is not necessarily as unique as it may initially appear. This article first goes through the history of land reform up until before the current period of Sandinista state power (starting in 2007). Then it presents the main points of the criticisms that have come up in Nicaragua of certain parts of certain periods of land reform and how that has influenced the continuation of the process. The following part gives a brief empirical account of land redistribution since 2007. Finally, a possible interpretation of the current state of land redistributions is presented.

\section{Literature Review}

Literature exists about the earlier periods of Nicaraguan policies related to agriculture and agricultural reform from (Biderman, 1983; Everingham, 2001; Román, 1975; Zalkin, 1990), but less so about the most recent phases after 1990, when the Sandinistas lost power, and since 2007, when Sandinistas returned to power. Román (1975) wrote about the inherent of the economic setup of the Somoza government and its inherent problems. Biderman (1983) looks at the development of Nicaraguan agriculture up until the early 1980s from the perspective of an economist. He gives a thorough picture of the years after the Second World War and the economic development policies in those years. Zalkin (1990) gives one of several accounts of the 1980s and the issues the agricultural reform processes faced at various stages. Everingham (2001) wrote on property rights in connection with the change of power in 1990. 


\section{Methodology}

I spent most of 2008 and 2009 researching the various policy fields of the Sandinista government since 2007, and three months in 2012 focusing on the question of land reform. I also spent shorter periods of time in Nicaragua in 2006/07, 2011 and 2014 without specific research goals. The research methodology has been a combination of long-term participant observation among political activists and land occupiers, in-depth interviews with key informants and political leaders as well as research in newspapers and existing scientific literature.

The first agrarian reform in the 1960s: Nicaraguan agricultural production processes did not undergo radical transformations in the first half of the 20th century. The US intervened militarily at the beginning of the century, promoting the build-up of a national oligarchy by turning land that was under indigenous and communal control into individually-owned land that could be bought and sold within a capitalist market, but without major improvements to technical tools and not focusing on soil preservation (Patten, 1971; Román, 1975; Winters, 1964). In the period 1925-49, overall yields per area dropped continuously, and by 1957-58 the yield per tree or hectare in Nicaragua was 50\% lower than Costa Rica or El Salvador (Biderman, 1983, pp. 10-12). This changed by the 1950s. The US-allied Somoza dictatorship started pushing for increased modernization within the agricultural sector. This modernization took the form of investments in agricultural machinery and infrastructure, as well as eventually import-substitution schemes to help national producers develop their production. With increased usage of machinery came a class that could afford the investment of acquiring tractors, etc., while most small-scale farmers continued using their traditional methods without high-level use of pesticides or other methods (Biderman, 1983; Irvin, 1982; Winters, 1964).

Additionally, with the introduction and subsequent growth of the cotton industry, large areas of land were required, and the way to obtain these was to drive small-scale farmers from their land. Measures that were employed to remove farmers were both legal and extralegal: Peasants with large loans could be forced off of their land through the judicial system, and those who did not have large debts could be scared away using violence and intimidation. By 1969, cotton production took up 75 percent of all cultivated land (Muro Rodríguez, 1984, p. 71). The government supported the process, which left many peasants landless-principally in the lower western zones of the country where the cotton fields were placed. Partially in response to this, the FSLN started its organizing efforts in 1961. Initially it focused mainly on the issues of peasants by proposing a land reform. At the same time, the government started with a limited land reform, handing out some lands to some of the displaced farmers. The agricultural reform under Somoza was likely meant to stop the revolutionary forces from advancing, yet it lacked in several areas, and was ultimately unsuccessful. Among its shortcomings was that the land that was handed out was located in a different part of the country, in the colder, more mountainous regions. The farmers had to move from their ancestral place to zones that oftentimes had not been cultivated before. The second reason was that, instead of receiving a land title or having their land ownership registered in the official books, they only received a paper signed or stamped by some local official. The validity of such makeshift titles was unclear at best, and it depended likely on whether or not someone close to the government would want the land themselves.

Agrarian reform under the Sandinistas in the 1980s: After the revolutionary insurrection, which brought the FSLN to power in 1979, land reform was one of the principal programs of the new government. Agriculture accounted for about $25 \%$ of GDP, about $50 \%$ of the labor force was employed in it and $70 \%$ of export earnings came from the agricultural sector (President of the International Development Association, 1980), so it was an important part of the economy. It was initially decided that the land that had previously belonged to the Somoza family, which accounted for around 25 percent of GDP at the end of the 1970s (Geske Dijkstra, 1999, p. 296), was to be distributed. In 1981, some more private lands were nationalized and handed out. The law stated that this would apply to a) lands that were under-efficiently used in production or rented out for profit of an extension of greater than 289 acres 1 on the Pacific coast or 578 acres in the rest of the country b) abandoned lands c) lands rented out for tenant farming of at least 29 acres on the Pacific cost or 58 acres in the rest of the country (Envío team, 1981). Land was handed out both to individual producers as well as cooperatives. In many cases, this was done without filing the changes in the official books, and when titles were given, this bore oftentimes restrictions on what the claim to the land meant (Fonseca Terán, 2008). A title given to a cooperative would generally say that the cooperative had a right and obligation to produce on the land, but that the cooperative could not sell commodities on the free market. In total about 60,000 families 
received land, either individually or collectively together with other families during this period (Tijerino, 2008).

The United States financed a brutal war against Nicaragua during much of the 1980s, with many of the contra-revolutionary merchants being former soldiers of the Somoza regime. The war destroyed most of the social advances the country had experienced during the early 1980s, and, with time, the Sandinistas lost support in the population. In 1990, when the FSLN lost national elections and had two months left before handing power over to a government from the political right, they spent much of that time formalizing the reform that had been done already. Sandinista critics have claimed that many Sandinista leaders used the process to enrich themselves, yet, in many cases, the evidence for this is questionable (Cupples, 1992).

The years of neoliberalism: When the political right had taken power, one of the first and most notable acts it did was to organize the disarmament of the Nicaraguan people. Both former Sandinista soldiers and contra-revolutionary fighters were Promised Land in exchange for giving up their arms (Everingham, 2001). While the government was largely successful in its disarmament efforts, with only a few military confrontations in some parts of the country throughout the 1990s, the promises of land distributions were generally not kept. Initially, the liberal government tried to reverse many of the redistributions that had been affected in the 1980s, but when confronted with mass protests organized by the Sandinistas, the liberals largely gave up. Instead, former land owners were reimbursed for their losses, and in many cases, they were even paid for land that was still under their control, but now formally formed part of the government's official landholdings. In the later years, land occupations were organized under the cover of protests demanding the land that had previously been promised to the formerly armed groups. In some cases, they were successful in doing so. At other times, they were removed by the police.

At this time, there were principally two ways of claiming property: through the official books, and through individually-held land titles given out during the 1980s. Additionally, some could still hold titles given out during the Somoza years. Others again would hold land de-facto, but without any formal registration of this fact. Who held which land was, therefore, increasingly confusing, and much of it was handled through the courts. Although the land titles of the 1980s were generally respected, the restrictions on them were not. This meant, for example, that some cooperatives were selling their lands illegally. The laws had not been changed, yet there was little enforcement. Combined with politics that aimed to impoverish small-scale producers, this caused a rollback of much of the agrarian reform. Cooperatives were generally not recognized as economic units, so it was difficult or impossible for them to receive financing as a cooperative. Land that had been held in co-op form, therefore, was split up to individual producers who could either qualify for agricultural credits, or who would sell their property.

Criticism of previous land reform: The criticism that can be recorded in Nicaragua today can be divided in two groups. The first criticism from those who are generally against any kind of land reform or aid for the poorer sections of society. Those Nicaraguans who have accumulated wealth and who still do not agree with the revolution of 1979 can generally be found in this category. Their criticism seems to be directly dependent on their own economic position, and there seems not to exist any real alternative proposed from this side. There is, therefore, little reason to consider this criticism any further. The other criticism is generally one by those who to start with have a positive view on redistribution programs, but who see some errors in their execution. This criticism is oftentimes uttered with an aim of improving possible future land distributions. The following are some of the issues that are mentioned most frequently. The policy under Somoza of removing farmers in order to set up cotton fields is, for obvious reasons, criticized for creating mono-culture, thereby destroying the earth in addition to forcing peasants to move away. The handing out of titles in the mountains during this time has been criticized as too little, and the titling process is criticized for existing in a legally ambiguous space, leading farmers to hold back on establishing themselves permanently.

Although it is much easier to find Nicaraguans criticizing the 1970s than the 1980s, even among Sandinistas the reform of the 1980s is oftentimes also portrayed as being imperfect. Some mention that production levels went down, and that less and less time was spent producing. I have heard this criticism as a criticism of Nicaraguan culture by Nicaraguans who claim that production levels went down, because time was spent discussing and making revolutionary plans rather than working in the field. A different argument is that peasants did not know how to produce their own land, and that although cooperatives were established, peasants could not produce in a cooperative manner; as individual producers, they 
would be able to work the land more efficiently. A criticism that I have only heard from the outside by westerners who were in Nicaragua in the 1980s is that some Sandinistas at the time thought it inconvenient for those employed in enormous agricultural businesses to obtain land and thereby become peasants, as peasants were notoriously known for being conservative and not willing to change. This problem is supposed to have created a division between agricultural workers and Sandinistas leaders and some see it as a main factor for the downfall of the Sandinistas in 1990. The politics of the neoliberal governments is criticized for not continuing the politics favoring cooperatives, for not handing out lands as it had promised, and for impoverishing the country side. However, the informal, mostly Sandinista-led, program of occupying areas and forcing an agricultural reform on the country is often criticized as well. There has not been much control over who has obtained lands, and who has not, some people are using their status as former fighters to legitimize taking land in one place, then selling it, only to occupy another piece of land; whereas most others never received land during this period.

The question of land during the current phase of Sandinista power: The current phase is likely the hardest to fully grasp, due to its complexity. The criticism of earlier stages of land redistribution seems to have been taken into account. Also the changed role of agriculture in the economy may be an important factor. Agriculture made out just $17.1 \%$ of GDP, employed $28 \%$ of the labor force in 2013 (CIA, 2014), while standing for around 53\% of exports in 2011 (OEC, 2012). One of the first concessions presidents Daniel Ortega made to the political right, who still held the majority in parliament when he took office, as well as the IMF and other international aid organizations, was that private property was to be respected. Ortega promised initially that no further land occupations were to occur during his new government (Sandoval, 2006). Nevertheless, land occupations have occurred. For example, I have witnessed land occupations over a longer period in both Ciudad Sandino and Granada in 2008-09. The Nicaraguan press has reported on many more in other parts of the country (Duarte, 2012; González, 2012). In the case of Ciudad Sandino, those organizing the occupation were former Contras, whereas those living there were just generally poor people from the area. Although the occupation was not formally in line with the politics of the government, the occupiers explained throughout my meetings with them that it was the office of Rosario Murillo, Ortega's wife that was key in helping organizers with the legalization process of the encampment. When I went back in 2012 to see what progress had been made, both electricity and water had been installed.

In the case of Granada, the organizers presented themselves to me as merely being "concerned citizens" unaffiliated with any party, but when I coincidentally ran into them at the city council, it became clear that they were employees of the Sandinista council group. The logic the Sandinista group tried to explain in the city council was, "although we condemned the illegal land occupation, we now have to set about to see how we can legalize the situation as it is". Even more noteworthy are the instructions the police receives from the presidency. In Ciudad Sandino in 2008, I interviewed the mayor, a member of the FSLN, who expressed strong disapproval of the police allegedly not following his orders to remove the land occupiers. Similarly, when landless Sandinista farmers, who claimed to have been active in the military during the 1980s, asked for 6 acres of land in March 2012, shut down a vital connection road at Sebaco, between the cities Matagalpa, Estelí and Managua, the police said that they "could not act without orders from the presidency." When I asked whether it was normal that such orders would not come immediately, the police man standing nearby answered: "Look, we police are not supposed to get involved in politics. My personal view is that previous governments would have tried to use physical force to remove them. Not so this one. What Daniel wants is negotiations." The police men around him all nodded in agreement. I have noticed this type of behavior and attitude on the part of Nicaraguan law enforcement officials repetitively since 2007 .

The limiting of the police in case of land occupations, as well as other social protests, strengthened the position of the protesters itself. Therefore, it is possibly the most crucial part in the government's hidden support for such occupations. It must be noticed, that in almost all cases of recent land distributions I have recorded, the land in question is small, and can hardly cover much more than a single house. It is therefore mostly a question of land for living, rather than land for production. Other aspects of the government's policies towards the small producers have to be seen in relation to the criticism of previous land reforms. Except for the production of sugar, there is an emphasis on producing small-scale and diversifying production to avoid the problems of cotton. The government rather ambitiously measures and hands out titles for lands that small producers already have in their control. This is meant to do away with the problems of peasants living in uncertainty regarding the legality of their land. The vanishing of cooperatives has been met with a new program for cooperatives. Special loans have been created for 
cooperatives, and the government has created a bank to target credits there. Some of the government aid programs are only available for those citizens who form a cooperative. As a result, the number of cooperatives has increased from about 2,711 in 2007 to 4,069 in January 2012 (Instituto del Cooperativismo en Nicaragua, 2012). Also, those titles that were created in the 1980s with conditions that were not fully respected in the 1990s are again seen as fully valid, including the restrictions placed upon them. Suddenly land sales that took place during this period can be deemed illegal, and the land has to return to the cooperative, that had stopped existing years ago.

Economic impact of redistribution policies after 1990: The effect of land reforms cannot easily be measured independently of the impact of other programs and factors not pertaining to any government policy. The primary outcome expected from land redistribution programs is mostly a higher level of economic equality. The most common measurements of economic difference are the Gini index, which measures the distribution of income or spendings within a specific population. Unfortunately, figures for the period prior to 1990 do not exist. Figures for the period after 1990 show a sharp decline in economic inequality (Table 1) during both the neoliberal and the second Sandinista period. Even though the land reform of the 1980s was the most profound, the country has seen much lower levels of inequality in the periods since. The impact of the land reform of the 1980s seems to not have lead to a lasting economically equal society. Its effect may have been canceled out by other factors, such as the cost of the war. In the subsequent period, inequality seems to have lowered dramatically, even though land reform was not part of an official government program. The absence of war is likely a contributing factor. Another factor often mentioned in Nicaragua is that the most wealthy have improved their skills at hiding their income from tax authorities. A third factor may be that the importance of land ownership is less important in an economy that has moved from mainly rural to mainly urban. In 1960, only $39.581 \%$ lived in urban areas, by 2013 that figure had grown to 58.1652\% (World Bank, 2014).

Table 1: Gini consumption index in Nicaragua (1993-2012)

\begin{tabular}{lll}
\hline & World Bank & FIDEG \\
\hline 1993 & 50.41 & \\
1998 & 45.24 & \\
2001 & 43.06 & \\
2005 & 40.47 & 40 \\
2009 & & 37 \\
2010 & & 35 \\
2011 & & 34 \\
2012 & & 33 \\
\hline
\end{tabular}

$0=$ completely equality, $100=$ complete inequality

Sources: (FIDEG, 2010, 2013; World Bank, 2014)

\section{Conclusion}

The question of land has been rather confusing in Nicaragua in the past, and also in the future is not likely to be resolved entirely in the near term. Nevertheless, it appears as if the current period is more stable than what any of the previous periods have been. This is a phase in which the rights of small producers are strengthened, and land distributed, but only so far as to ensure living spaces. No new areas for small producers are created, but those who do exist are encouraged to produce in the form of cooperatives, rather than as individual small farmers. The most valuable part of government policy towards helping social movements in general, and also those in the agricultural sector, seem to be the hesitancy to employ the police to physically remove protesters, and the willingness to compromise in order to secure social peace. It is unclear whether there is a strategy on what those who obtain the small parcels near principal cities are meant to do with their lives. When asking FSLN officials concretely, the answer is mostly, "build micro-companies and cooperatives within tourism". Tourism is where many Sandinistas currently see most potential for Nicaragua, but it remains unclear whether entering the tourism industry is a realistic 
choice for those living in the newly created city zones at the outskirts of the cities with at least initially much less sophisticated infrastructure.

It must also be said that there are exceptions and that some land occupations cover somewhat larger areas. For example, the group that had occupied a significant access street in March 2012 was asking for land to be used for agricultural production. And when in 2012 I tried to find one of the two Contras who had initially organized the land occupation in Ciudad Sandino, she was busy organizing a land occupation for peasant farmers somewhere far away from the cities and near the coast. The role of the Sandinistas in relation to land reforms since the 1980s seems, nevertheless, to have changed. It lies outside of the range of this article to say whether this is due a change in interest in reforming the countryside due to the economic rise of many Sandinista families, or whether obtaining a piece of land is not as relevant for the economic survival of a family as it was previously. At the same time, economic equality seems to be improving. This may point to land reforms being less important for economic equality than it was previously thought.

\section{References}

Biderman, J. (1983). The Development of Capitalism in Nicaragua. Latin American Perspectives, 10(1), 732.

CIA. (2014). Nicaragua. The World Factbook 2013. Retrieved May 19, 2014, from https://www.cia.gov/library/publications/the-world-factbook/geos/nu.html

Cupples, J. (1992). Ownership and Privatization in Post-Revolutionary Nicaragua. Bulletin of Latin American Research, 11(3), 295-306.

Duarte, I. (2012). Creciente problema en toma de terrenos baldíos en Granada. El Nuevo Diario. Managua. Retrieved from http://www.elnuevodiario.com.ni/departamentales/241348-crecienteproblema-toma-de-terrenos-baldios-granada

Envío Team. (1981). The Agrarian Reform Law In Nicaragua. Revista Envío, (3). Retrieved from http://www.envio.org.ni/articulo/3099

Everingham, M. (2001). Agricultural Property Rights and Political Change in Nicaragua. Latin American Politics and Society, 43(3), 61-93.

FIDEG. (2010). Encuesta de Hogares para la Medición de la Pobreza en Nicaragua, FIDEG 2009. Managua: Fundación Internacional para el Desafío Económico Global. Retrieved from http://fideg.org/files/doc/1283290135_Resultados\%20FIDEG\%202009web.pdf

Fonseca-Terán, C. (2008). Zorros del mismo piñal. El Nuevo Diario. Retrieved from http://www.elnuevodiario.com.ni/opinion/21537

FIDEG. (2013). Encuesta de Hogares para la Medición de la Pobreza en Nicaragua, FIDEG 2012. Managua: Fundación Internacional para el Desafío Económico Global. Retrieved from http://www.fideg.org/images/INFORME_DE_LA_ENCUESTA_DE_HOGARES_FIDEG_2012.pdf

Geske-Dijkstra, A. (1999). Technocracy Questioned: Assessing Economic Stabilization in Nicaragua. Bulletin of Latin American Research, 18(3), 295-310. doi:10.1111/j.1470-9856.1999.tb00136.x

González, J. L. (2012). Toma de tierras en Sutiaba, León. El Nuevo Diario. Managua. Retrieved from http://www.elnuevodiario.com.ni/departamentales/238705

Instituto del Cooperativismo en Nicaragua. (2012). Desarollo del cooperativismo en Nicaragua (2008 a enero 2012). Managua.

Irvin, G. (1982). The Nicaraguan Economy. Social Scientist, 10(1), 36-43.

Rocha, J. L. (2010). The Contradictory Legacy of the Sandinista Agrarian Reform. Revista Envío, 2(348). Retrieved from http://www.envio.org.ni/articulo/4212

Land reform reformed. (1997). The Economist. Retrieved from http://www.economist.com/node/456173

Muro Rodríguez, M. (1984). Nicaragua y La Revolucion Sandinista. Havana: Editorial De Ciencias Sociales.

OEC. (2012). Products exported by Nicaragua (2011). Retrieved May 19, 2014, from http://atlas.media.mit.edu/explore/tree_map/hs/export/nic/all/show/2011/

Patten, G. P. (1971). Dairying in Nicaragua. Annals of the Association of American Geographers, 61(2), 303315.

President of the International Development Association. (1980). President's Report and Recommendation to the Executive Directors on a Proposed Credit to the Republic of Nicaragua for a preinvestment fund project (No. P-2916-NI). World Bank. Retrieved from http://wwwwds.worldbank.org/external/default/WDSContentServer/WDSP/IB/1999/08/04/000178830_9 8101902363447/Rendered/PDF/multi_page.pdf 
Román, J. W. (1975). Imperialismo y Dictadura: crisis de una formación social. Mexico City: Siglo XXI.

Sandoval, C. (2006). Ortega promete cero tomas de tierras. El Nuevo Diario. Managua. Retrieved from http://impreso.elnuevodiario.com.ni/2006/11/09/politica/33445

Tijerino, F. K. (2008). Historia de Nicaragua (3rd ed.). Managua: Instituto de Historia de Nicaragua y Centroamérica, Universidad Centroamericana.

Winters, D. H. (1964). The Agricultural Economy of Nicaragua. Journal of Inter-American Studies, 6(4), 501-519.

World Bank. (2014). World dataBank. Retrieved July 20, 2014, from http://databank.worldbank.org/

Zalkin, M. (1990). The Sandinista Agrarian Reform: 1979-1990? International Journal of Political Economy, 20(3), 46-68.

\section{Abbreviations}

FSLN: Frente Sandinista de Libración Nacional 